\title{
Peran Dan Tanggung Jawab Kepala Sekolah Dan Guru Dalam Pengembangan Kurikulum
}

\author{
Juahab \\ Kepala Sekolah SDN Nunang Kecamatan Janapria \\ juahab@gmail.com
}

\begin{abstract}
Abstrak
Peran adalah sebuah perilaku yang diharapkan dapat menerangkan yang harus dilakukan dalam suatu situasi tertentu baik secara formal maupun informal. Sedangkan tanggung jawab adalah suatu kewajiban untuk melakukan peran atau tingkah laku yang disengaja maupun tidak disengaja menurut cara tertentu.

Peran kepala sekolah dalam pengembangan kurikulum yaitu sebagai menejer, dan leader (pemimpin). Sedangkan tanggung jawabnya sebagai kepala sekolah yaitu sebagai pengelola pendidikan dan sebagai pemimpin formal.

Peran guru dalam pengembangan kurikulum, menurut Murry Print ada 4 level yaitu sebagai pengembang kurikulum atau designing, peneliti kurikulum atau planning, implementers, dan adapter atau evaluating. Sedangkan dari segi pengelolaannya, peran guru dalam pengembangan kurikulum itu dapat dibedakan antara tiga sifat yaitu yang bersifat sentralilasi,desentralisasi dan sentral desentral. Adapun tanggung jawab guru dalam pengembangan kurikulum yaitu sebagai pengajar, pembimbing, pengembang kurikulum, pengembang profesionalnya dan dapat membina hubungan dengan masyarakat.
\end{abstract}

Kata Kunci: Peran Dan Tanggung Jawab Kepala Sekolah 


\section{A. LATAR BELAKANG}

Dalam studi tentang ilmu mengajar dan kurikulum, permasalahan yang dialami oleh kepala sekolah dan guru senantiasa mendapat tempat tersendiri. Itu dikarenakan peran dan tanggung jawab kepala sekolah dan guru sangat penting dalam keberhasilan suatu pendidikan. Berdasarkan pandangan yang ada sekarang ini, betapapun bagus dan indahnya kurikulum itu pada akhirnya bergantung pada masing-masing guru.

Pengembangan kurikulum itu melibatkan banyak pihak, terutama guru yang bertugas di kelas. Setiap kepala sekolah dan guru mengemban tanggung jawab secara aktif dalam perencanaan, pelaksanaan, penilaian, pengadministrasian dan perubahan kurikulum. Sejauhmana keterlibatan guru akan turut menentukan keberhasilan pengajaran di sekolah.

Keberhasilan kurikulum itu sebagian besar ada ditangan guru selaku pelaksana dari kurikulum. Para guru bertanggung jawab sepenuhnya dalam pelaksanaan kurikulum, baik secara keseluruhan maupun sebagai tugas yang berupa penyampaian bidang studi atau mata pelajaran yang sesuai dengan program yang dirancang kurikulum.

Berdasarkan hal tersebut, maka perlu kiranya pemakalah membahas tentang peran dan tanggung jawab kepala sekolah dan guru dalam pengembangan kurikulum.

\section{B. PEMBAHASAN}

1. Pengertian Peran dan Tanggung Jawab

a) Pengertian Peran

Sering kita mendengar kata peran yang dikaitkan dengan posisi atau kedudukan seseorang. Mungkin tak banyak orang tahu, bahwa kata peran atau role dalam bahasa Inggrisnya, memang diambil dari dramaturgy atau seni teater. Dalam seni teater seorang aktor diberi peran yang harus dimainkan sesuai dengan plot-nya, alur ceritanya, dan lakonnya.

Kata peran atau role dalam kamus oxford dictionary diartikan Actor's part, one's task or function. Yang berarti actor, tugas seseorang atau fungsi. Istilah peran dalam Kamus Besar Bahasa Indonesia mempunyai arti pemain sandiwara (film), tukang lawak pada permainan makyong, perangkat tingkah yang diharapkan dimiliki oleh orang yang berkedudukan di masyarakat.

Menurut Friedman peran adalah serangkaian perilaku yang diharapkan pada seseorang sesuai dengan posisi sosial yang diberikan baik secara formal maupun secara informal. Peran didasarkan pada ketentuan dan harapan peran yang menerangkan apa yang individuindividu harus lakukan dalam suatu situasi tertentu agar dapat memenuhi harapan-harapan mereka sendiri atau harapan orang lain menyangkut peran-peran tersebut.

b) Pengertian Tanggung Jawab

Setiap manusia harus mempunyai rasa tanggung jawab, dimana rasa tanggung jawab itu harus disesuaikan dengan apa yang telah kita lakukan. Arti dari tanggung jawab menurut kamus bahasa indonesia 
adalah keadaan wajib menanggung segala sesuatunya. Sehingga bertanggung jawab menurut kamus umum bahasa indonesia adalah berkewajiban memikul, menanggung segala sesuatunya dan menanggung segala akibatnya.

Tanggung jawab adalah kesadaran manusia akan tingkah laku atau perbuatannya yang disengaja maupun yang tidak disengaja. Tanggung jawab juga berarti berbuat sebagai perwujudan kesadaran akan kewajibannya. Tanggung jawab itu bersifat kodrati, artinya sudah menjadi bagian kehidupan manusia, bahwa setiap manusia pasti dibebani dengan tanggung jawab.

Ridwan Halim mendefinisikan tanggung jawab sebagai suatu akibat lebih lanjut dari pelaksanan peranan, baik peranan itu merupakan hak maupun kewajiban ataupun kekuasaan. Secara umum tanggung jawab diartikan sebagai kewajiban untuk melakukan sesuatu atau berperilaku menurut cara tertentu.

Tanggung jawab adalah ciri manusia yang beradab. Manusia merasa bertanggung jawab karena ia menyadari akibat baik atau buruk perbuatannya dan menyadari pula bahwa pihak lain memerlukan pengadilan atau pengorbanan.

2. Peran dan Tanggung Jawab Kepala Sekolah dalam Pengembangan Kurikulum

a) Peran Kepala Sekolah dalam Pengembangan Kurikulum ada dua peran kepala sekolah dalam pengembangan kurikulum pendidikan dasar yaitu:

1) Kepala Sekolah Sebagai Menejer

Tugas menejer adalah merencanakan, mengorganisasikan, mengatur, mengkoordinasikan dan mengendalikan dalam rangka mencapai tujuan yang telah ditetapkan. Manajer adalah orang yang melakukan sesuatu secara benar (people who do things right). ${ }^{1}$ Dengan demikian, kepala sekolah harus mampu merencanakan dan mengatur serta mengendalikan semua program yang telah disepakati bersama.

Dalam mengelola tenaga pendidikan, salah satu tugas penting yang harus dilakukan kepala sekolah adalah melaksanakan kegiatan pemeliharaan dan pengembangan profesi para guru. Dalam hal ini kepala sekolah hendaknya dapat memfasilitasi dan memberikan kesempatan yang luas kepada guru untuk melaksanakan kegiatan pengembangan profesi melalui berbagai kegiatan pendidikan dan pelatihan, baik yang dilaksanakan sekolah, atau melalui kegiatan pendidikan dan pelatihan diluar sekolah.

2) Kepala sekolah sebagai leader (pemimpin)

Dalam teori kepemimpinan setidaknya kita mengenal dua gaya kepemimpinan yaitu kepemimpinan yang berorientasi pada tugas dan kepemimpinan yang berorientasi pada manusia. Dalam rangka meningkatkan kompetensi guru, seorang kepala sekolah dapat

${ }^{1}$ Vincent Gaspersz. 2003. Total Quality Management. Jakarta: PT. Gramedia Pustaka Utama. Hlm. 201 
menerapkan kedua gaya kepemimpinan tersebut secara tepat dan fleksibel, disesuaikan dengan kondisi dan kebutuhan yang ada. Menurut John Gage Allee, "Leader is a guide, a conductor and a commander."2 (Pemimpin itu adalah penunjuk pemandu, penuntun dan komandan). Kepribadian kepala sekolah sebagai leader menurut Ordway Tead harus menunjukkan sifat-sifat:

- Kesadaran akan tujuan dan arah

- Antusiasme

- Keramahan dan kecintaan

- Integritas (keutuhan, kejujuran dan ketulusan hati)

- Penguasaan teknis

- Ketegasan dalam mengambil keputusan

- Kecerdasan

- Keterampilan mengajar

- Kepercayaan

b) Tanggung Jawab Kepala Sekolah dalam Pengembangan Kurikulum

Sebagai pengelola pendidikan berarti kepala sekolah bertanggung jawab terhadap keberhasilan penyelenggaraan kegiatan pendidikan dengan cara melaksanakan administrasi sekolah dengan seluruh substansinya. Disamping itu, kepala sekolah juga bertanggung jawab terhadap kualitas sumber daya manusia yang ada agar mereka mampu menjalankan tugas-tugas pendidikan. Sebagai pengelola, kepala sekolah memiliki tugas untuk mengembangkan kinerja para personal (terutama para guru) ke arah profesionalisme yang diharapkan.

Sebagai pemimpin formal, kepala sekolah bertanggung jawab atas tercapainya tujuan pendidikan melalui upaya menggerakkan para bawahan ke arah pencapaian tujuan pendidikan yang telah ditetapkan. Dalam hal ini kepala sekolah bertugas melaksanakan fungsi-fungsi kepemimpinan, baik fungsi yang berhubungan dengan pencapaian tujuan pendidikan maupun penciptaan iklim sekolah yang kondusif bagi terlaksananya proses belajar mengajar secara efektif dan efisien. ${ }^{3}$

Tanggung jawab atau amanah merupakan beban yang harus dipikul dan melekat pada seorang kepala sekolah yang harus dipertanggung jawabkan dalam organisasi dan dihadapan Allah kelak, sekaligus sebagai peluang untuk beribadah kepada Allah serta memberikan manfaat bagi orang lain. Hal ini tergambar dalam hadits yang artinya "Tidak akan bergeser telapak kaki seseorang hamba pada hari kiamat, sehingga ia ditanya tentang empat hal, yaitu tentang umurnya, bagaimana ia habiskan, tentang masa mudanya,bagaimana ia lewatkan, tentang hartanya, bagaimana ia dapatkan dan kemana ia infakkan, dan tentang ilmunya, bagaimana ia mengamalkannya."(HR Tirmidzi).

2John Gage Allee. 1969. Webster's New Standar Dictionary. New York: Mc Loughlin Brothers Inc. HIm. 214

${ }^{3}$ Moch Idhochi Anwar. 2003. Administrasi Pendidikan dan Manajemen Biaya Pendidikan. Bandung: CV Alfabeta. Hlm.75 
Tanggung jawab juga berkaitan dengan resiko yang dihadapi oleh seorang pemimpin, baik berupa sanksi dari atasan atau pihak lain yang berhubungan dengan perbuatan yang dilakukan, maupun yang dilakukan oleh bawahan, guru, karyawan dan tenaga kependidikan. Tanggung jawab seorang pemimpin harus dibuktikan bahwa kapan saja dia harus siap untuk melaksanakan tugas. Dia harus tetap siaga bila ada perintah dari yang lebih atas. Untuk itu, dia harus seorang pekerja keras (hard worker), berdedikasi (dedicated employer), dan seorang saudagar (memiliki seribu akal). ${ }^{4}$

c) Peran dan Tanggung Jawab Guru dalam Pengembangan Kurikulum

1) Peran Guru dalam Pengembangan Kurikulum

Bagaimanapun idealnya suatu kurikulum tanpa ditunjang oleh kemampuan guru untuk mengimplementasikannya, maka kurikulum itu tidak akan bermakna sebagai suatu alat pendidikan, dan sebaliknya pembelajaran tanpa kurikulum sebagai pedoman tidak akan efektif. Dengan demikian peran guru adalah sebagai posisi kunci dan dalam pengembangnnya guru lebih berperan banyak dalam tataran kelas.

Murray Printr mencatat peran guru dalam beberapa level yaitu sebagai berikut:

a) Guru sebagai pengembang kurikulum atau designing, guru memiliki kewenangan dalam mendesain sebuah kurikulum. Guru bukan saja dapat menentukan tujuan dan isi pelajaran yang disampaikan, akan tetapi juga dapat menentukan strategi apa yang harus dikembangkan serta bagaimana mengukur keberhasilannya. Sebagai pengembang kurikulum sepenuhnya guru dapat menyusun kurikulum sesuai dengan karakteristik, visi dan misi sekolah, serta sesuai dengan pengalaman belajar yang dibutuhkan siswa.

b) Guru sebagai peneliti kurikulum (curriculum researcher) atau planning. Peran ini dilaksanakan sebagai bagian dari tugas profesional guru yang memiliki tanggung jawab dalam meningkatkan kinerjanya sebagai guru. Biasanya metode yang digunakan oleh guru dalam meneliti kurikulum adalah Penelitian Tindakan Kelas (PTK) dan Lesson Study.

c) Guru sebagai implementers, guru berperan untuk mengaplikasikan kurikulum yang sudah ada. Dalam melaksanakan, peran guru hanya menerima berbagai kebijakan perumusan kurikulum, dalam pengembangan kurikulum guru dianggap sebagai tenaga teknis yang hanya bertanggung jawab dalam mengimplementasikan berbagai ketentuan yang ada.

d) Guru sebagai adapters atau evaluating, peran guru lebih dari pelaksana kurikulum, akan tetapi guru juga sebagai penyelaras

${ }^{4}$ E.Mulyasa. 2005. Pedoman Manajemen Berbasis Madrasah. Jakarta:

Departemen Agama RI, Direktorat Jenderal Kelembagaan Agama Islam. Hlm.54 -55 
kurikulum dengan karakteristik dan kebutuhan siswa dan kebutuhan daerah.

Sedangkan dilihat dari segi pengelolaannya, peran guru dalam pengembangan kurikulum dapat dibedakan antara yang bersifat sentralisasi, desentralisasi, dan sentral desentral. ${ }^{5}$

a) kurikulum yang bersifat sentralisasi, maksudnya guru tidak mempunyai peranan dan evaluasi kurikulum yang bersifat makro, mereka lebih berperan dalam kurikulum mikro. Kurikulum makro disusun oleh tim khusus yang terdiri atas para ahli. Penyusunan kurikulum mikro dijabarkan dari kurikulum makro. Guru menyusun kurikulum dalam bidangnya untuk jangka waktu satu tahun, satu semester, beberapa minggu, atau beberapa hari saja.

Kurikulum untuk satu tahun disebut prota, dan kurikulum untuk satu semester disebut dengan promes. Sedangkan kurikulum untuk beberapa minggu, beberapa hari disebut Rencana Pembelajaran. Program tahunan, program semester ataupun rencana pembelajaran memiliki komponenkomponen yang sama yaitu tujuan, bahan pelajaran, metode dan media pembelajaran dan evaluasi hanya keluasan dan kedalamannya berbedabeda.

b) kurikulum yang bersifat desentralisasi, maksudnya kurikulum disusun oleh sekolah ataupun kelompok sekolah tertentu dalam suatu wilayah atau daerah. Kurikulum ini diperuntukkan bagi suatu sekolah ataupun lingkungan wilayah tertentu. Pengembangan kurikulum semacam ini didasarkan atas karakteristik, kebutuhan, perkembangan daerah serta kemampuan sekolah-sekolah tersebut. Dengan demikian, isi daripada kurikulum sangat beragam, tiap sekolah atau wilayah mempunyai kurikulum sendiri tetapi kurikulum ini cukup realistis.

c) Kurikulum yang bersifat sentral desentral, Untuk mengatasi kelemahan kedua bentuk kurikulum tersebut, bentuk campuran antara keduanya dapat digunakan yaitu bentuk sentral-desentral. Dalam kurikulum yang dikelola secara sentralisasi-desentralisasi mempunyai batas-batas tertentu, peran guru dalam pengembangan kurikulum lebih besar dibandingkan dengan yang dikelola secara sentralisasi. Guru turut berpartisipasi, bukan hanya dalam penjabaran kurikulum induk ke dalam program tahunan, semester atau rencana pembelajaran, tetapi juga di dalam menyusun kurikulum yang menyeluruh untuk sekolahnya. Guru-guru turut memberi andil dalam merumuskan dalam setiap komponen dan unsur dari kurikulum. Dalam kegiatan yang seperti itu, mereka mempunyai perasaan turut memilki kurikulum dan terdorong untuk mengembangkan pengetahuan dan kemampuan dirinya dalam pengembangan kurikulum.

Karena guru-guru sejak awal penyusunan kurikulum telah diikutsertakan, mereka memahami dan benar-benar menguasai kurikulumnya, dengan demikian pelaksanaan kurikulum di dalam kelas

\footnotetext{
${ }^{5}$ Nana Syaodih Sukmadinata. 1999. Pengembangan Kurikulum Teori dan Praktek. Bandung: PT Remaja Rosdakarya. Hlm. 199
} 
akan lebih tepat dan lancar. Guru bukan hanya berperan sebagi pengguna, tetapi perencana, pemikir, penyusun, pengembang dan juga pelaksana dan evaluator kurikulum.

2) Tanggung Jawab Guru dalam Pengembangan Kurikulum

Setiap guru mengemban tanggung jawab secara aktif dalam perencanaan, pelaksanaan, penilaian, pengadministrasian, dan perubahan kurikulum. Sejauh mana keterlibatan guru akan turut menentukan keberhasilan pengajaran di sekolah.

Tugas guru sebenarnya bukan hanya disekolah saja, tetapi bisa dikatakan dimana saja mereka berada. Di rumah, guru sebagai orang tua yang mana mereka mendidik putra dan putrinya. Di dalam masyarakat sekitar yaitu masyarakat kampung, desa tempat tinggalnya guru sering kali terpandang sebagai tokoh suri tauladan bagi orang-orang disekitarnya, baik dalam sikap dan perbuatannya misalnya cara dia berpakaian, berbicara dan bergaul, maupun pandangan-pandangannya. Peters mengemukakan ada tiga tanggung jawab guru yaitu:

- Guru sebagai pengajar,

- guru sebagai pembimbing,

- guru sebagai administrator.

Peters dan Amstrong membagi tanggung jawab guru menjadi lima kategori yaitu:

a) Guru bertanggung jawab dalam pengajaran. Tanggung jawab guru yang terpenting ialah memberikan pengajaran kepada siswa guna mencapai pertumbuhan dan perkembangan yang diinginkan. Guru harus membimbing siswa agar mereka memperoleh keterampilan-keterampilan, pemahaman, perkembangan berbagai kemampuan, kebiasaan-kebiasaan yang baik, dan perkembangan sikap serasi.

b) Guru bertanggung jawab dalam memberikan bimbingan. Guru memberi tekanan kepada tugas, memberikan bantuan kepada siswa dalam pemecahan masalah yang dihadapinya. Tugas ini merupakan aspek mendidik, sebab tidak hanya berkenaan dengan penyampaian ilmu pengetahuan tetapi juga menyangkut pengembangan kepribadian dan pembentukan nilai-nilai para siswa. Guru perlu menghormati pribadi anak, supaya mereka menjadi pribadi yang tahu akan hak-hak orang lain. Kebiasaan, sikap, dan apresiasinya harus dikembangkan, hingga pada waktunya mereka menjadi manusia yang mengerti akan hak dan tanggung jawab sebagai anggota masyarakat yang berdiri sendiri. Karena itu guru harus memahami benar tentang masalah bimbingan belajar, bimbingan pendidikan, bimbingan pribadi, dan terampil dalam memberikan penyuluhan dengan tepat.

c) Guru bertanggung jawab dalam mengembangkan kurikulum. Sesungguhnya guru merupakan seorang key person yang paling mengetahui tentang kebutuhan kurikulum yang sesuai dengan tingkat perkembangan siswa. Untuk mengubah kurikulum itu bukan tidak mungkin, akan tetapi dalam rangka mambuat atau memperbaiki proyekproyek pelaksanaan kurikulum, yang berhubungan dengan tugas dan 
tanggung jawabnya. Paling tidak dia berkewajiban memberi saran-saran yang berguna demi penyempurnaan kurikulum kepada pihak yang berwenang. Dalam hubungan ini guru dapat melakukan banyak hal, antara lain menyarankan ukuran-ukuran yang mungkin dapat digunakan dalam memilih bahan kurikulum, berusaha menemukan minat, kebutuhan dan kesanggupan siswa, berusaha menemukan cara-cara yang tepat agar antara sekolah dan masyarakat terjalin hubungan kerja sama yang seimbang, mempelajari isi dan bahan pelajaran pada setiap kelas dan meninjaunya dalam hubungan dengan praktek sehari-hari.

d) Tanggung jawab dalam mengembangkan profesional guru. Guru sangat perlu meningkatkan peranan dan kemampuan profesionalnya. Tanpa adanya kecakapan yang maksimal yang dimiliki oleh guru maka kiranya sulit bagi guru tersebut mengembangkan dan melaksanakan tanggung jawabnya dengan cara yang sebaik-baiknya. Peningkatan kemampuan itu meliputi kemampuan untuk melaksanakan tanggung jawab dalam melaksanakan tugas-tugas di dalam sekolah dan kemampuannya yang diperlukan untuk merealisasikan tanggung jawabnya di luar sekolah. Kemampuan-kemampuan itu harus dipupuk dalam diri pribadi guru sejak ia mengikuti pendidikan guru sampai ia bekerja.

e) Tanggung jawab dalam membina hubungan dengan masyarakat. Guru tak mungkin melaksanakan pekerjaannya secara efektif, jika seorang guru tidak mengenal masyarakat seutuhnya dan secara lengkap. Harus dipahami dengan baik tentang pola kehidupan, kebudayaan, minat, dan kebutuhan masyarakat, karena perkembangan sikap, minat, aspirasi anak sangat banyak dipengaruhi oleh masyarakat sekitarnya. Ini berarti, bahwa dengan mengenal masyarakat, guru dapat mengenal siswa dengan menyesuaikan pelajarannya secara aktif.

\section{DAFTAR PUSTAKA}

Allee, John Gage. 1969. Webster's New Standar Dictionary. New York: Mc Loughlin Brothers Inc.

Anwar, Moch Idhochi. 2003. Administrasi Pendidikan dan Manajemen Biaya Pendidikan. Bandung: CV Alfabeta.

Departemen Pendidikan Nasional. 2005. Kamus Besar Bahasa Indonesia. Jakarta: Balai Pustaka.

Gaspersz, Vincent. 2003. Total Quality Management. Jakarta: PT. Gramedia Pustaka Utama.

Mulyasa, E. 2005. Pedoman Manajemen Berbasis Madrasah. Jakarta: Departemen Agama RI, Direktorat Jenderal Kelembagaan Agama Islam.

Sukmadinata, Nana Syaodih. 1999. Pengembangan Kurikulum Teori dan Praktek. Bandung: PT Remaja Rosdakarya. 